A Nation of
Counterfeiters 



\section{A Nation of Counterfeiters}

C A P I TALISTS, C O N M E N,

A N D T H E M A K I N G O F

T H E U N I T E D S T A T E S

S TE PHE N M I H M

HARVARD UNIVERSITY PRESS Cambridge, Massachusetts London, England 
Copyright (C) 2007 by Stephen Mihm

All rights reserved

Printed in the United States of America

First Harvard University Press paperback edition, 2009.

Publication of this book has been supported through the generous provisions of the Maurice and Lula Bradley Smith Memorial Fund.

Figures I, I3, I4, I5, 23, and 26 are used, with permission, from Q. David Bowers, Obsolete Paper Money Issued by Banks in the United States, I782-I866, copyright (C) 2006 Whitman Publishing, LLC. All Rights Reserved.

Portions of Chapter I appeared previously as "The Alchemy of the Self: Stephen Burroughs and the Counterfeit Economy of the Early Republic," Early American Studies 2 (Spring 2004): 123-159. The material appears here by permission of the McNeil Center for Early American Studies and the University of Pennsylvania Press.

Library of Congress Cataloging-in-Publication Data

Mihm, Stephen, 1968-

A nation of counterfeiters : capitalists, con men, and the making of the United States / Stephen Mihm.

p. $\mathrm{cm}$.

Includes bibliographical references and index.

ISBN 978-0-674-02657-5 (cloth : alk. paper)

ISBN 978-o-674-03244-6 (pbk.)

I. Bank notes-Forgeries-United States. 2. Banks and banking-United States.

3. Counterfeits and counterfeiting-United States. I. Title.

$\mathrm{HG}_{33} 6 . \mathrm{U}_{5} \mathrm{M}_{54} 2007$

332.I0973'09034-dc22 200700974I 
For Silas 
